\section{1. 海綿静脈洞部硬膜動静脈瘻の血管内治療}

自治医科大学血管内治療部

根本 繁

硬膜動静脈瘻（DAVF）は, 静脈洞の閉塞性変化に伴う動 静脈シャントが病態であり, 静脈圧六進の改善と動静脈シャ ント遮断が治療目標となる，海綿静脈洞部病変では開頭術が 適応となる症例はなく, 血管内治療が第一選択となっている. 動脈塞栓術では, 治療後早期に根治する可能性は低く, 液体 塞栓物質を使用する場合にはリスクを伴う。静脈塞栓術は根 治性が高いが，静脈還流を考慮して，静脈洞を閉塞する必要 がある，海綿静脈洞部 DAVF は自然治癒する症例もあり，軽 症例では経過観察することが多い. 海綿静脈洞へのアプロー チには, 下錐体静脈洞経由, 顔面静脈経由, 上眼静脈経由が あり，症例に応じて選択する。静脈塞栓術後に外眼筋麻痺が 悪化する症例があるが，ほとんどが一過性であり，静脈洞血 栓化によるものと考えられる．網膜中心静脈血栓症を伴う場 合には視力低下をきたし, 失明する可能性があり, 早期治療 が必要となる。

\section{2. 横・S 状静脈洞部硬膜動静脈瘻の治療}

富山医科薬科大学脳神経外科

桑山 直也

硬膜動静脈瘻は硬膜内での硬膜動脈と硬膜静脈の後天的吻 合である。横・S 状静脈洞部硬膜動静脈瘦は本邦では海綿静 脈洞部についで多く, 性差がない. 症状・症候は流出路の形 態により決定され，単なる耳鳴のみを呈する軽症のものから 頭蓋内出血を生ずる重症のものまで様々である. 本セッショ ンではまず流出路の形態による分類（Djindjan \& Merland, Borden, Lalwani）を紹介し, 硬膜動静脈瘻の血行動態につい て考察する，次に分類に基づいた治療を血管内治療（transarterial embolization, transvenous embolization, transarterial venous embolization, direct sinus packing), 外科治療 (sinus skeletonization, sinus removal, selective venous clipping), 放 射線療法，およびこれらの併用療法に分け，それらの具体的 な方法，治療成績，合併症を中心に解説する.

\section{3. 脊髄血管奇形の外科治療}

東北大学脳神経外科

富永 悌二

Dural AVF は venous congestionをきたす胸腰部と主に SAHをきたす頭蓋頸椎移行部の 2 群があり，いずれも drainer 遮断が必要である. 外科的遮断の方が血管内手技より も閉塞率が高い. 胸腰部群の長期予後は, 運動機能の改善に 比し感覚障害は悪化する場合もあり，早期発見治療が必要で ある. Perimedullary AVF は， shunt 閉塞が原則であり，脊髄 前面に位置する頸部は椎体切除による前方アプローチが有用 である。しかし脊髄円錐から馬尾に存在する場合, Spetzler 等が提唱している conus medullaris AVM に合致し，血管撮影 では把握しきれない multiple shunt を有しており，この部位 の特殊な血管解剖を理解して治療しなければならない，症例 を提示しながら，それぞれを解説する。 